\title{
Peningkatan Pengetahuan dan Keterampilan Pemuda Putus Sekolah Melalui Pelatihan Perawatan Berkala Sepeda Motor
}

\author{
Nuzul Hidayat ${ }^{1 *}$, Ahmad Arif ${ }^{1}$, M. Yasep Setiawan ${ }^{1}$, Wanda Afnison ${ }^{1}$ \\ ${ }^{1}$ Jurusan Teknik Otomotif, Fakultas Teknik, Universitas Negeri Padang \\ *Corresponding author, e-mail: nuzulhidayat@ft.unp.ac.id
}

\begin{abstract}
Abstrak - Nagari Batu Basa merupakan salah satu nagari yang termasuk ke dalam wilayah Kec. Pariangan, Kab. Tanah Datar, Provinsi Sumatera Barat dengan jumlah penduduk 4.262 jiwa. Hampir $40 \%$ pemuda di daerah ini tidak memiliki pekerjaan tetap dikarenakan putus sekolah sehingga tidak memiliki ijazah untuk melamar pekerjaan. Karena jumlah sepeda motor yang cukup banyak pada nagari ini, maka salah satu peluang lapangan pekerjaan yang dapat diciptakan pemuda putus sekolah adalah usaha bengkel sepeda motor. Tujuan program pelatihan ini adalah untuk meningkatkan pengetahuan dan keterampilan perawatan/ servis berkala sepeda motor dan kemudian dapat membuka lapangan kerja sendiri dalam bidang jasa perawatan/servis sepeda motor. Pelatihan ini menggunakan metode ceramah, tanya jawa, demonstrasi dan bimbingan melalui modul atau buku saku pelatihan serta praktek langsung perawatan berkala pada sepeda motor masing-masing peserta pelatihan. Setelah pelaksanaan pelatihan, pemuda putus sekolah memiliki peningkatan pengetahuan tentang cara menggunakan sepeda motor yang baik dan benar sehingga dapat memperpanjang masa pemakaian sepeda motor. Disamping itu juga meningkatkan pengetahuan dan keterampilan pemuda putus sekolah mengenai perawatan berkala sepeda motor sehingga diharapkan mampu membuka lapangan pekerjaan berupa jasa perawatan (service) sepeda motor di daerah Kenagarian Batu Basa Kec. Pariangan Kab.Tanah Datar.
\end{abstract}

Kata kunci: Pelatihan, Perawatan Berkala, Sepeda Motor, Pemuda Putus Sekolah.

Abstract - Nagari Batu Basa is one of the nagari belonging to the region of Kec. Pariangan, Kab. Tanah Datar, West Sumatra Province with a population of 4,262 inhabitants. Nearly $40 \%$ of youth in this area have no permanent job due to dropping out of school so they do not have a diploma to apply for a job. Due to the considerable number of motorcycles in this village, one of the job opportunities that can be created by youth dropping out is a motorcycle workshop. The purpose of this training program is to improve the knowledge and skills of motorcycle periodic maintenance and then to open their own field work in the field of motorcycle maintenance services. This training uses lecture method, question answer, demonstration and guidance through a module or pocket book of training as well as regular practice of regular maintenance on each participant's motorcycle. After the implementation of the training, out-of-school youth have an increased knowledge of how to use a motorcycle that is good and correct so that it can extend the life of the motorcycle. Besides, it also increases the knowledge and skills of the drop out youth regarding the periodic maintenance of motorcycles so that it is expected to be able to open employment field in the form of motorcycle maintenance services in the area of Nagari Batu Basa Kec. Pariangan Kab.Tanah Datar.

Keywords : Training, Periodic Maintenance, Motorcycles, Youth Drop Out

This is an open access article distributed under the Creative Commons 4.0 Attribution License, which permits unrestricted use, distribution, and reproduction in any medium, provided the original work is properly cited. (C2018 by Author and Universitas Negeri Padang

\section{Pendahuluan}

Jorong sialahan yang jauh dari pusat pemerintahan Kabupaten Tanah Datar yang masih terisolir ini memiliki dampak negatif terhadap pendidikan masyarakat yang ada di jorong sialahan ini. Kondisi ini dibuktikan dengan banyaknya pemuda putus sekolah. Kondisi ini memperburuk keadaan masyarakat Jorong Sialahan Kenagarian Batu Bata. Dilain sisi sepeda motor sudah merupakan kebutuhan yang sangat penting bagi masyarakat. Hampir setiap masyarakat 
menggunakan sepeda motor sebagai transportasi manusia maupun sebagai transportasi barang dalam memindahkan hasil pertanian ke pasar.

Sebuah sepeda motor tidak bisa digunakan secara terus menerus akan mengalami kerusakan jika tidak dirawat dengan baik [1]. Pemahaman ini sangat penting bagi masyarakat yang menggunakan sepeda motor, karena sebagian besar masyarakat kurang memperhatikan hal ini sehingga terjadi kerusakan-kerusakan yang fatal yang mengakibatkan sepeda motor menjadi tidak berfungsi menurut yang semestinya. Disamping itu juga masyarakat tidal memahami dan mengikuti penggunaan buku pedoman perawatan kendaraan bermotor [2],[3]. Selanjutnya dengan adanya pemahaman tentang perawatan sepeda motor maka masyarakat juga bisa menjadikan ini sebagai usaha baru disamping pekerjaan sebagai petani.

Berdasarkan permasalahan tersebut, maka perlu dilaksanakan program pelatihan dengan judul "Pelatihan Perawatan Berkala Pada Sepeda Motor bagi Pemuda Putus Sekolah di Nagari Batu Basa Kec. Pariangan Kab. Tanah Datar". Dengan pelatihan ini diharapkan dapat meningkatkan pengetahuan dan keterampilan pemuda putus sekolah dalam perawatan sepeda motor secara berkala.

\section{STUdi PUSTAKa}

Pengetahuan dan keterampilan disebut juga dengan kompetensi. Kompetensi diartikan sebagai pengetahuan, keterampilan, dan kemampuan yang dikuasai oleh seseorang yang telah menjadi bagian dari dirinya, sehingga dapat melakukan perilakuperilaku kognitif, afektif, dan psikomotor dengan sebaik-baiknya [4]. Kompetensi mencakup tugas, keterampilan, sikap, dan apresiasi yang harus dimiliki oleh seseorang agar dapat melaksanakan tugas-tugas yang dipelajarinya sesuai dengan kemampuan yang diperlukan oleh dunia kerja.

Kompetensi perawatan berkala sepeda motor meliputi: (1) memeriksa setiap sistem pada sepeda motor untuk memastikan sistem tersebut masih berfungsi dan bekerja dengan baik; (2) membersihkan bagian pada setiap sistem yang kotor agar kotoran yang ada tidak merusak sistem; (3) mengatur atau menyetel kembali bagian sistem yang berubah agar sesuai dengan standar spesifikasinya; (4) Memperbaiki atau mengganti komponen sepeda motor yang rusak atau aus agar performa sepeda motor kembali optimal.

Sepeda motor adalah kendaraan beroda dua yang digerakkan oleh sebuah mesin. Letak kedua roda sebaris lurus dan pada kecepatan tinggi sepeda motor tetap stabil disebabkan oleh gaya giroskopik. Sedangkan pada kecepatan rendah, kestabilan atau keseimbangan sepeda motor bergantung kepada pengaturan setang oleh pengendara. Penggunaan sepeda motor di Indonesia sangat populer karena harganya yang relatif murah, terjangkau untuk sebagian besar kalangan dan penggunaan bahan bakarnya serta biaya operasionalnya cukup hemat [5].

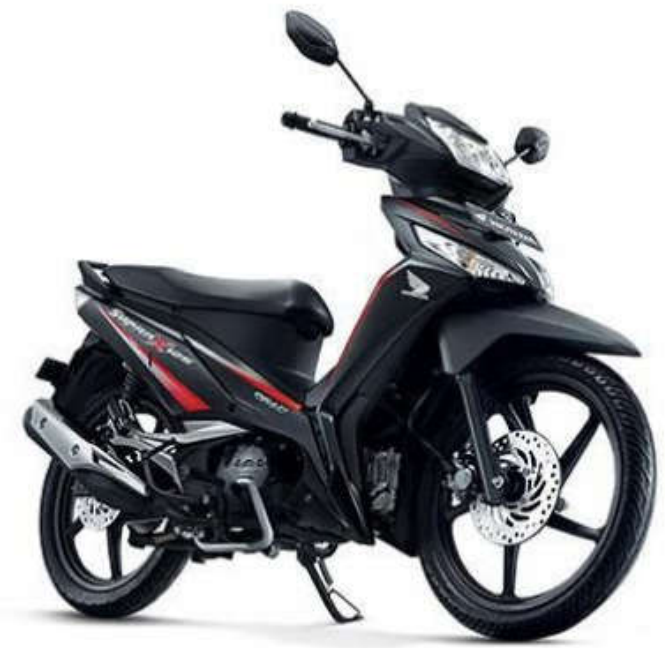

Gambar 1. Jenis sepeda motor bebek yang paling banyak dipakai masyarakat

Bagian-bagian utama motor yang penting untuk diketahui agar dapat dan layak beroperasi pada dasarnya terdiri dari beberapa bagian utama yang membentuk suatu sistem, sistem inilah yang memungkinkan sepeda motor beroperasi dan berfungsi dengan baik. Engine (mesin) sepeda motor secara umum engine berfungsi sebagai sumber tenaga untuk menggerakan/mengooperasikan kendraan engine yang digunakan pada sepeda motor adalah engine pembakaran dalam (internal combustion engine) yang pada umumnya menggunakan bensin [3].

Kelistrikan adalah seluruh rangkaian yang ada pada sepeda motor kelistrikan berfungsi sebagai pendukung unjuk kerja kendaraan yang mencakup kelistrikan mesin seperti sistem pengapian untuk memercikan bunga api pada busi, kelistrikan bodi seperti sistem penerangan, lampu panel /indikator dan kelengkapan kelistrikan lainnya. Chasis berfungsi sebagai dudukan ( penempatan ) seluruh komponen yang membentuk kendraan serta mengontrol jalannya kendaraan chasis terdiri dari beberapa unit yaitu : rangka berfungsi sebagai dudukan/penempatan seluruh bagian kendraan seperti mesin (engine) cover body, sistem kelistrikan, unit pengendali, dan lain-lain. 


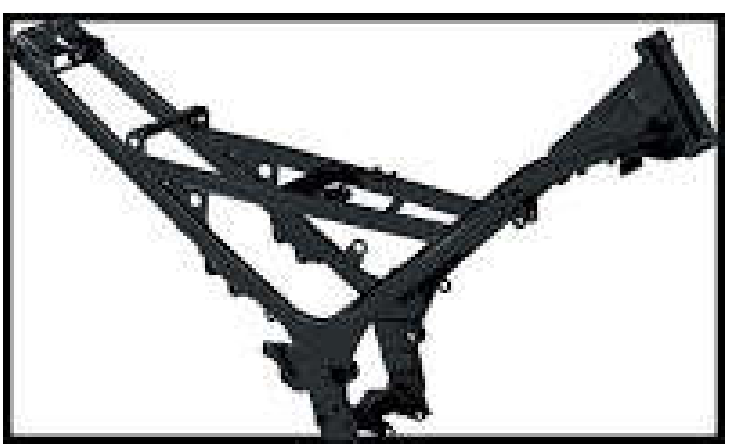

Gambar 2. Rangka sepeda motor

Pemindah tenaga berfungsi untuk memindahkan tenaga mesin ke roda dalam prosesnya, pemindah tenaga melakukan peningkatan momen penggerak pada roda dan merubah kecepatan kendaraan, pemindah tenaga ini terdiri dari kopling, transmisi, rantai, sprocket dan roda.

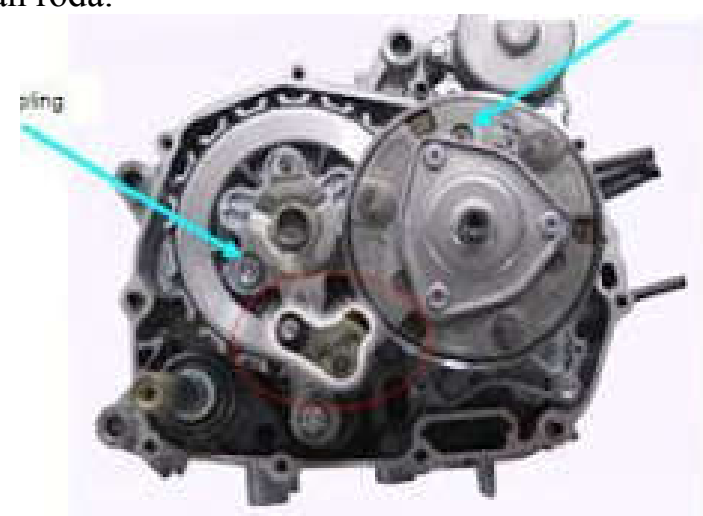

Gambar 3. Sistem pemindah tenaga

Kemudi berfungsi untuk mengarahkan jalannya kendaraan pengendalian arah kendaraan dilakukan dengan mengatur posisi roda umumnya kendaraan menggunakan roda depan sebagai penentu arah kendaraan kemudi ini terdiri dari stang kemudi ( handle bar ), batang kemudi ( steering steam ), garpu depan ( front fork ).

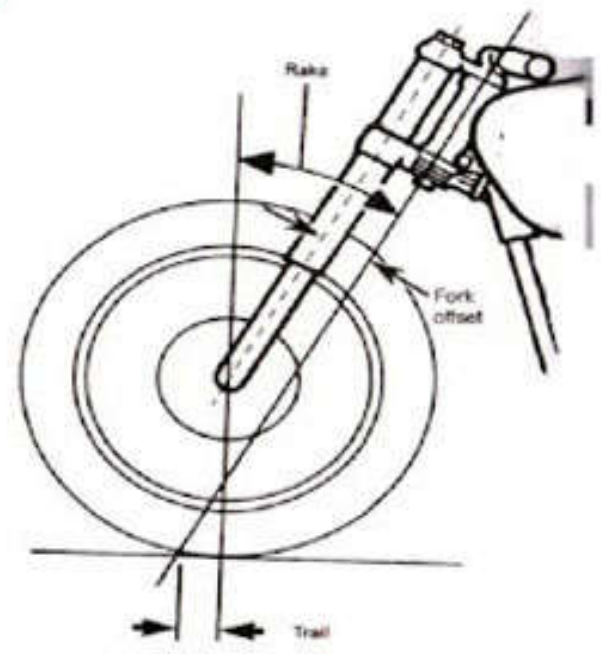

Gambar 4. Sistem kemudi

Secara umum rem berfungsi untuk memperlambat jalannya kendaraan rem berfungsi untuk menghentikan kendaraan pengoperasian rem dapat dilakukan secara mekanik, hidrolik, pneumatic atau kombinasi ketiganya pada sepeda motor umurnya hanya menggunakan rem mekanik dan hidrolik.
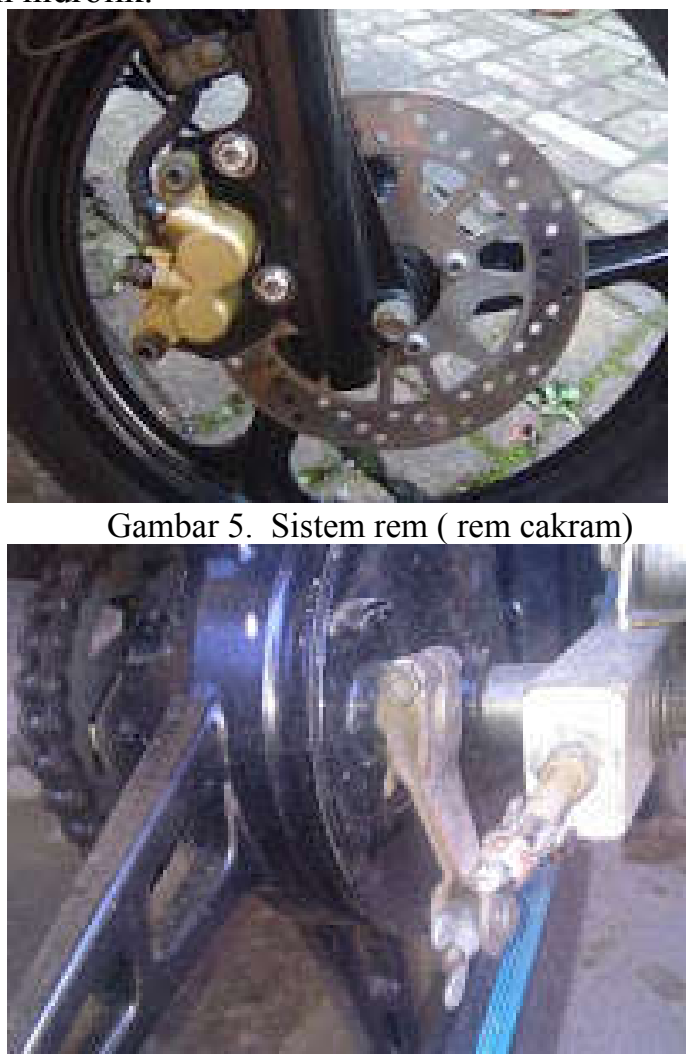

Gambar 6. Sistem rem ( rem tromol)

Sebagai bahan bakar engine ini adalah merupakan bagian utama dari suatu kendaraan pada engine juga terdapat sistem pendinginan, sistem pelumasan, sistem pengapian, mekanisme katup, dan bagian-bagian mesin itu sendiri.

Setiap sepeda motor yang dioperasikan, pada akhirnya akan mengalami suatu keadaan dimana bagian-bagian dari sepeda motor tersebut (mesin, transmisi, rangka, dsb) mengalami kelelahan dan keausan sehingga mengurangi kinerjanya, diantaranya: tenaga mesin menurun, akselerasi lambat, bahan bakar boros, dan kemungkinan kerusakan berlanjut/merembet terhadap kerusakan komponen yang lainnya. Apabila kondisi tersebut tidak ditanggulangi melalui perawatan berkala kendaraan, maka kondisi tersebut akan meningkat ke arah kerusakan komponen yang bertambah parah dan membutuhkan dana yang cukup besar untuk mengembalikan sepeda motor pada kondisi semula [6].

Perawatan atau Pemeliharaan berkala, yaitu segala upaya yang dilakukan untuk mempertahankan kondisi suatu peralatan atau 
mesin sehingga selalu dalam kondisi optimal dan selalu siap untuk dioperasikan. Pemeliharaan/ perawatan terencana dikerjakan atas dasar sejauhmana atau berapa lama kendaraan telah berjalan (dalam $\mathrm{km}$ atau bulan). Diharapkan dengan dilakukannya perawatan berkala dengan baik, maka akan diperoleh keuntungan usia komponen/kendaraan lebih lama, konsumsi bahan bakar lebih ekonomis, tenaga mesin optimal, kadar polusi/emisi gas buang kendaraan lebih rendah dan keamanan/ keselamatan yang tinggi [7].

\section{METODE}

Penelitian ini merupakan penelitian terapan yang bertujuan untuk melatih kompetensi pemuda putus sekolah melalui pemahaman dan keterampilan dalam perawatan/pemeliharaan sepeda motor. Pelatihan ini merupakan upaya pelayanan bagi masyarakat khususnya memberikan pemahaman dan pentingnya perawatan sepeda motor secara berkala sehingga sepeda motor dapat berfungsi menurut semestinya.

Pelatihan ini diikuti oleh 15 orang pemuda putus sekolah yang dilaksanakan selama 2 hari di Nagari Batu Basa Kec. Pariangan Kab. Tanah Datar. Untuk mengetahui peningkatan pengetahuan dan kompetensi perawatan berkala sepeda motor bagi pemuda putus sekolah, maka dilakukan evaluasi awal sebelum pelatihan dimulai dan evaluasi akhir setelah pelatihan selesai. Semua peralatan dan bahan yang dibutuhkan selama pelatihan disediakan oleh tim pelaksana, sedangkan sepeda motor yang digunakan dalam pelatihan adalah sepeda motor milik setiap peserta. Dengan pelatihan ini diharapkan pemuda putus sekolah dapat memiliki pengetahuan dan keterampilan perawatan berkala sepeda motor terutama sepeda motor mereka sendiri maupun masyarakat di sekitarnya sehingga mampu membuka lapangan pekerjaan berupa jasa perawatan (service) sepeda motor di daerah Kenagarian Batu Basa Kec. Pariangan Kab.Tanah Datar.

Pelatihan dilakukan dengan metode ceramah dan tanya jawab, demonstrasi dan pemberian tugas serta bimbingan. Metode ceramah dan tanya jawab digunakan untuk menjelaskan pengetahuan dan memperkenalkan jenis keterampilan yang akan diberikan secara teoritis serta ditampilkan dalam bentuk media presentasi power point dan gambar animasi. Metode demonstrasi dan pemberian tugas digunakan untuk memberikan pengetahuan dan keterampilan kepada peserta dalam hal pemeliharaan sistem-sistem sepeda motor dan akan diberikan tugas agar materi yang didapatkan bisa dipraktekkan secara mandiri. Metode bimbingan dilakukan selama proses pelatihan berlangsung dalam bentuk memandu dan membantu kendalakendala yang dihadapi peserta selama pelatihan berlangsung maupun setelah pelaksanaan.

\section{HASIL DAN PEMBAHASAN}

Untuk melihat hasil yang telah dicapai, dilakukan evaluasi saat kegiatan berlangsung dan akhir kegiatan pelatihan.

\section{A. Evaluasi saat kegiatan.}

\section{Kehadiran.}

Jumlah peserta yang mengikuti pelatihan adalah 15 orang sesuai dengan yang direncanakan. Semua peserta dapat mengikuti pelatihan dari awal sampai akhir kegiatan dengan penuh kedisiplinan. Pelatihan dipadatkan 2 hari Sabtu dan Minggu tanggal 30 September sampai 1 Oktober 2017 mulai jam 08.00-17.00 WIB. Meskipun pelatihan dilaksanakan pada hari sabtu dan minggu, peserta pelatihan tetap antusias dan semua peserta dapat mengikuti pelatihan dengan baik.

\section{Sikap dan Antusiasme peserta pelatihan.}

Selama pelatihan berlangsung sikap dan antusiasme peserta pelatihan sangat tinggi. Hal ini dapat dilihat dari sikap peserta pelatihan yang tidak mau meninggalkan tempat pelatihan. Disamping itu peserta pelatihan juga disiplin dalam mematuhi jadwal yang telah ditetapkan oleh panitia. Peserta pelatihan masuk jam 08.00 WIB dan pulang jam 17.00 WIB. Saat jam istirahat peserta pelatihan memanfaatkan waktu dengan berdiskusi dengan instruktur dan memahami modul dan buku saku pelatihan. Panitia pelaksana pelatihan sangat kooeperatif dan saling mendukung aktifitas dari peserta pelatihan tersebut. Semua panitia terlibat aktif membantu dalam keterlaksanaan kegiatan pelatihan.

\section{Keiingintahuan peserta pelatihan sangat tinggi.}

Hal ini dapat dilihat dari keseriusan peserta dalam mendengarkan materi dan melaksanakan perintah yang diberikan oleh instruktur. Peserta pelatihan dapat melihat dan mempelajari modul yang diberikan, jika peserta pelatihan mempunyai kendala peserta pelatihan tidak ragu untuk bertanya pada instruktur. Banyak peserta pelatihan yang belajar mandiri dari modul yang diberikan oleh panitia. Terdapat juga beberapa peserta pelatihan yang dapat mengerjakan latihan praktek perawatan sepeda motor hanya dengan cepat tanpa kendala 
yang berarti. Jika peserta pelatihan ada kendala, peserta pelatihan dapat bertanya kepada tim instruktur.

Peserta pelatihan aktif selama pelatihan berlangsung.

Selama kegiatan peserta pelatihan aktif mengerjakan latihan praktek yang diberikan instruktur. Peserta pelatihan mampu menyeleseikan perawatan/ servis sepeda motor yang diberikan. Beberapa peserta pelatihan yang cepat menyeleseikan tugas yang diberikan instruktur, melakukan proses bimbingan serta bantuan kepada peserta-peserta lain yang belum menyeleseikan tugas yang diberikan instruktur pelatihan.

\section{Dokumentasi tahapan dan metode pelatihan}

Dokumentasi seluruh tahapan dan metode yang digunakan dalam pelatihan dapat dilihat pada gambar 7 sampai gambar 10 .

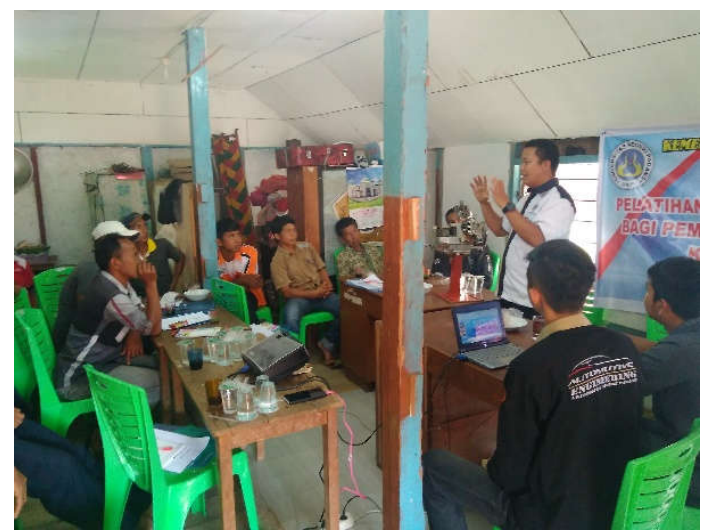

Gambar 7. Aktifitas kegiatan evaluasi awal dan penyajian materi secara teoritis.

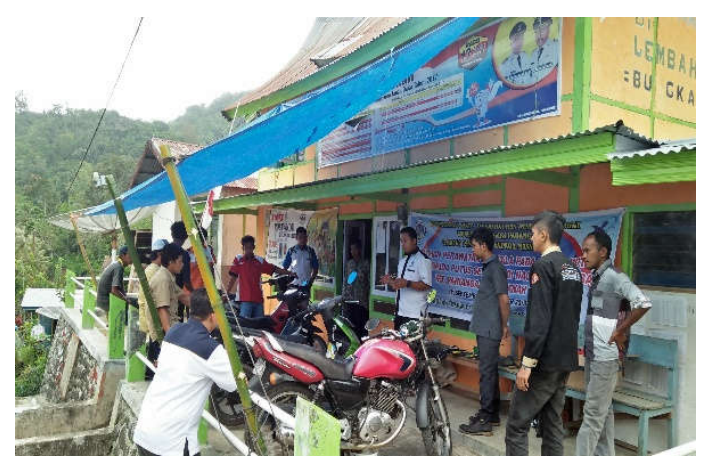

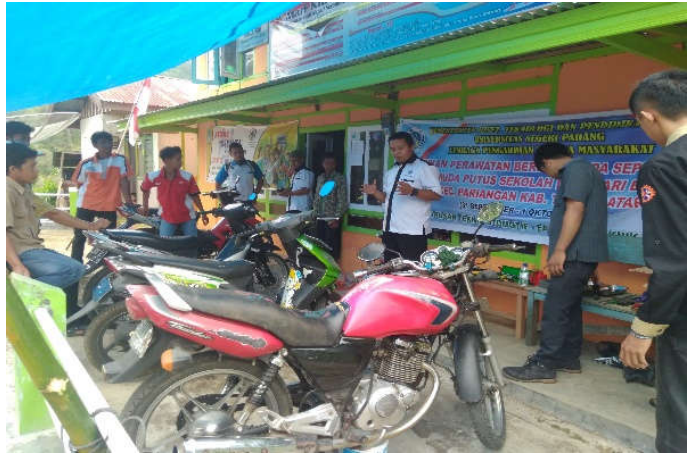

Gambar 8. Aktifitas kegiatan mendemontrasikan cara menggunakan sepeda motor yang benar.
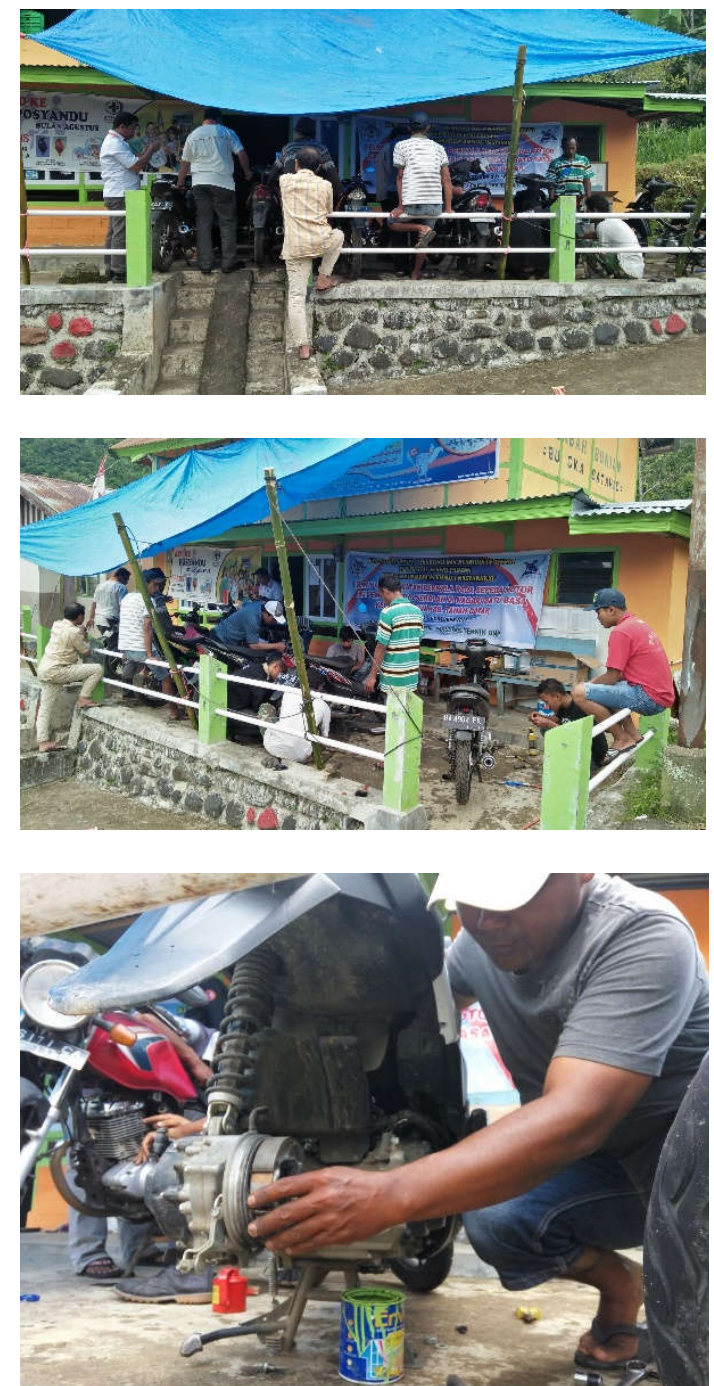

Gambar 9. Aktifitas kegiatan mendemontrasikan dan praktek langsung peserta tentang langkah-langkah perawatan berkala sepeda motor. 

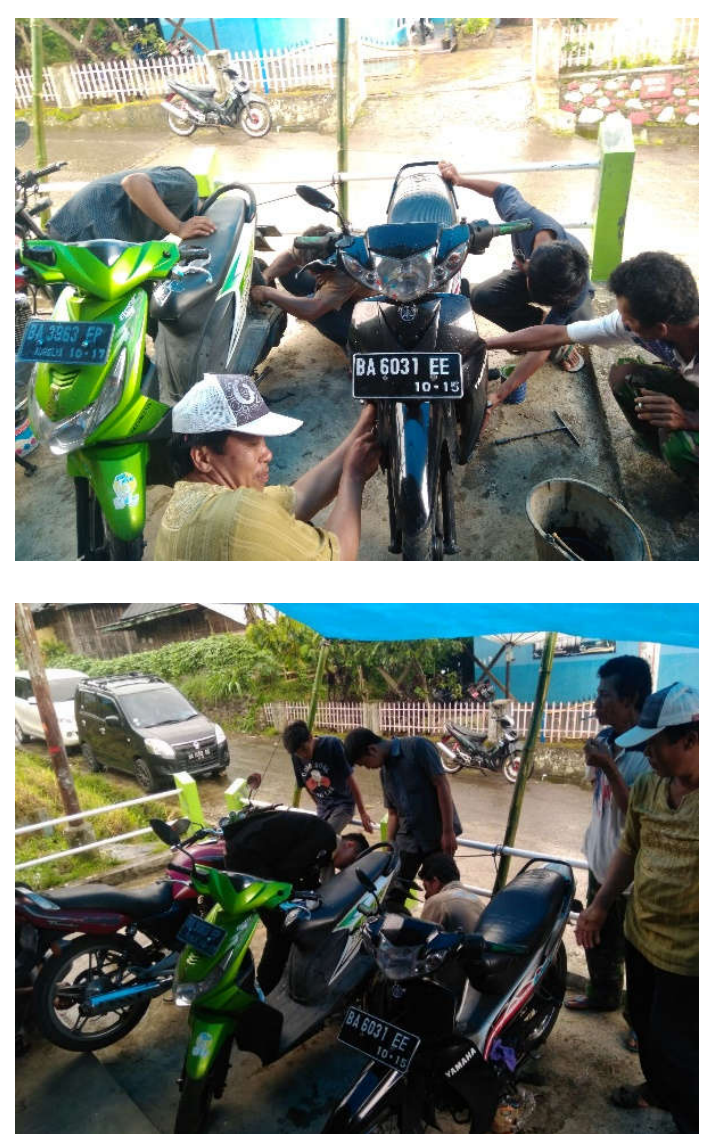

Gambar 10. Bimbingan langsung kepada peserta pelatihan.

\section{B. Evaluasi akhir kegiatan.}

Evaluasi akhir dilakukan dengan melihat hasil akhir perawatan/ servis berkala yang dilakukan peserta pelatihan pada sepeda motornya masingmasing. Hasil akhir peserta pelatihan dievaluasi tentang semua pengetahuan dan keterampilan perawatan/ servis berkala sepeda motor oleh instruktur pelatihan. Berdasarkan hasil evaluasi awal dan akhir kegiatan pelatihan yang dilakukan didapatkan hasil kemampuan pengetahuan dan keterampilan peserta pelatihan meningkat secara signifikan. Sebelum dilakukan pelatihan, semua peserta pelatihan belum memiliki kemampuan untuk melakukan perawatan/ servis berkala.

Setelah diberikan materi dan dilakukan praktek langsung kepada peserta pelatihan, maka terdapat peningkatan kemampuan pengetahuan dan keterampilan peserta pelatihan. Hal ini dapat dilihat dari pada gambar 5 .

Selain itu, kegiatan pelatihan ini juga menghasilkan luaran berupa buku saku pembelajaran berisi panduan lengkap perawatan berkala sepeda motor dan mendapatkan 1 liter oli pelumas untuk sepeda motor yang digunakan oleh peserta untuk bahan prakteknya.

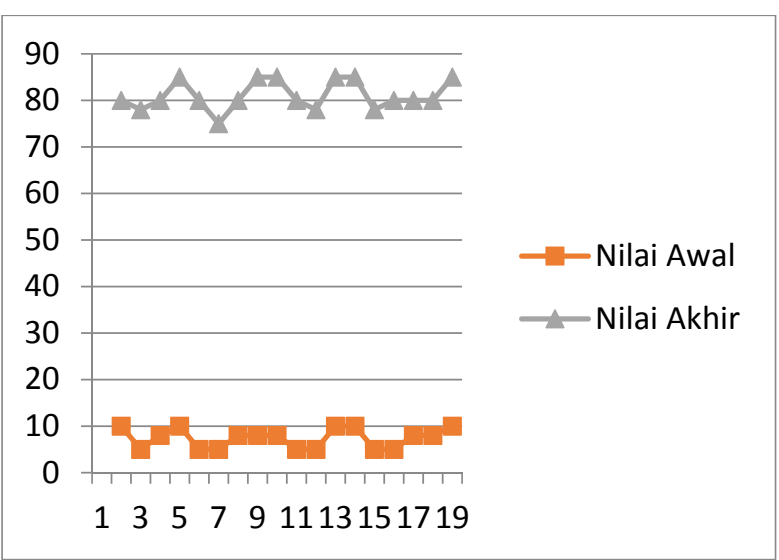

Gambar 5. Grafik peningkatan pengetahuan dan keterampilan peserta pelatihan.

\section{Pembahasan.}

Sasaran kegiatan pelatihan ini dapat dicapai sesuai dengan yang diharapkan. Ini dapat dilihat dari hasil akhir nilai pengetahuan dan keterampilan yang telah diperoleh oleh peserta pelatihan. Peserta pelatihan mampu melakukan perawatan berkala sepeda motor sesuai proseur. Peserta pelatihan juga mampu memahami cara menggunakan sepeda motor yang baik dan benar sesuai dengan latihan yang diberikan.

Selama pelatihan peserta mempunyai kedisplinan dalam mengikuti pelatihan. Peserta pelatihan juga memiliki percaya diri yang tinggi terhadap kemampuan yang telah mereka miliki. Hal ini terlihat dari antusiame peserta pelatihan yang semangat berdiskusi dengan panitia dan instruktur mengenai trubleshooting kerusakan yang biasanya terjadi pada sepeda motor.

Peserta pelatihan juga berharap agar kegiatan pelatihan ini bisa diperpanjang, sehingga mereka bisa terus meningkatkan kemampuan perawatan berkala sepeda motor maupun memperbaiki kerusakan-kerusakan yang jarang terjadi. Karena keterbasan waktu, peserta pelatihan merasa perlu banyak waktu lagi untuk memantapkan keterampilan perawatan berkala sepeda motor.

Komunikasi antara instruktur dengan peserta pelatihan juga tidak terputus meskipun pelatihan sudah berakhir. Beberapa peserta pelatihan menghubungi instruktur untuk menanyakan beberapa kendala dalam peserta pelatihan temui dalam merawat/ servis sepeda motor secara mandiri. Instruktur juga menyediakan waktu untuk membimbing peserta pelatihan baik melalui media sosial, telepon maupun peserta datang ke kampus. 


\section{KESIMPULAN}

Dalam kegiatan pelatihan perwatan berkala sepeda motor dapat disimpulkan bahwa kegiatan pengabdian kepada masyarakat ini dimaksudkan untuk membantu pemuda putus sekolah cara menggunakan sepeda motor yang baik dan benar sehingga dapat memperpanjang masa pemakaian sepeda motor. Disamping itu juga menambah pengetahuan dan keterampilan pemuda putus sekolah mengenai perawatan berkala sepeda motor sehingga diharapkan mampu membuka lapangan pekerjaan berupa jasa perawatan (service) sepeda motor di daerah Kenagarian Batu Basa Kec. Pariangan Kab.Tanah Datar. Antusias masyarakat saat kegiatan sangat tinggi ini dibuktikan dengan kehadiran, partisipasi, dan kedisiplinan dalam kegiatan pelatihan ini.

\section{DAfTAR PUStaka}

[1] Astra Honda Motor. Pengetahuan Produk. Jakarta: Astra Honda Training Center.

[2] Astra Honda Motor. Buku Pedoman Reparasi Honda Supra X 125. Jakarta: PT. Astra Honda Motor.

[3] Suratman (2003). Servis dan Teknik Reparasi Sepeda Motor. Bandung: CV. Pustaka Grafika.

[4] Lapisa, R., Basri, I. Y., Arif, A., dkk. (2017). Peningkatan Kompetensi Siswa Melalui Pelatihan Auto Cad. INVOTEK: Jurnal Inovasi Vokasional dan Teknologi, 17(2), 119-126.

[5] Sudjarwo (2013). Pemeliharaan Mesin Sepeda Motor. Jakarta: Kementerian Pendidikan dan Kebudayaan.

[6] Nugraha, B. S. (2005). Modul Tune-Up Sepeda Motor. Yogyakarta. FT-UNY.

[7] Nurhadi, Maskuri, Walid, A. dkk. (2016). Pelatihan Tune Up Sepeda Motor Sebagai Upaya Meningkatkan Skill Generasi Muda di Wilayah Kecamatan Blimbing Kota Malang. Seminar Nasional Hasil Pengabdian Kepada Masyarakat. 179-184.

\section{BiodataPenulis}

Nuzul Hidayat, dilahirkan di Tigo Suku, 16 Januari 1987. Menyelesaikan S1 pada program studi Pendidikan Teknik Otomotif Jurusan Teknik Otomotif FT - UNP Padang tahun 2010 dan pendidikan Pascasarjana (S2) Magister Teknik di jurusan Teknik Mesin Program Pascasarjana ITS Surabaya dengan bidang konsentrasi Rekayasa Konversi Energi pada tahun 2013. Sejak tahun 2013 sampai sekarang menjadi staf pengajar di jurusan Teknik Otomotif FT - UNP.
Ahmad Arif, lahir di Padang Panjang, 27 Februari 1989. Pendidikan S1 di program studi Pendidikan Teknik Otomotif jurusan Teknik Otomotif FT UNP Padang dan lulus tahun 2012. Tahun 2013 2015 melanjutkan pendidikan S2 di program studi Rekayasa Konversi Energi jurusan Teknik Mesin Program Pascasarjana ITS Surabaya. Selanjutnya menjadi staf pengajar di Jurusan Teknik Otomotif FT - UNP sejak tahun 2015 sampai sekarang.

M. Yasep Setiawan, lahir di Salimpauang, 30 September 1989. Sarjana Pendidikan di Jurusan Teknik Otomotif FT - UNP 2011. Tahun 2014 memperoleh gelar Magister Teknik di program studi Rekayasa Konversi Energi jurusan Teknik Mesin Program Pascasarjana ITS Surabaya. Staf pengajar di Jurusan Teknik Otomotif FT - UNP sejak tahun 2015 sampai sekarang.

Wanda Afnison, dilahirkan di Sariak Laweh, 9 April 1989. Menyelesaikan S1 pada program studi Pendidikan Teknik Otomotif Jurusan Teknik Otomotif FT - UNP Padang tahun 2011 dan pendidikan Pascasarjana (S2) Magister Teknik di jurusan Teknik Mesin Program Pascasarjana ITS Surabaya dengan bidang konsentrasi Desain Sistem Mekanikal pada tahun 2015. Sejak tahun 2015 sampai sekarang menjadi staf pengajar di jurusan Teknik Otomotif FT - UNP. 
